\title{
Characteristics of specific reading disability in children from a neuropsychological clinic in Mexico City
}

\author{
Adrián Poblano, MC, M en RN, (1) Sonia Borja, MC, (1) Yolanda Elías, MC, ${ }^{(1)}$ \\ Felipe García-Pedroza, MC, M en PH, (1) Ma de Lourdes Arias, MC. (1)
}

\begin{abstract}
Poblano A, Borja S, ElíasY, García-Pedroza F,Arias ML. Characteristics of specific reading disability in children from a neuropsychological clinic in Mexico City. Salud Publica Mex 2002;44:323-327. The English version of this paper is available too at: http://www.insp.mx/salud/index.html

A bstract

Objective.This report describes the main clinical features associated with specific reading disability (RD) in a group of 778 school-age children studied in a N europsychological Clinic in Mexico City. Material and Methods. The study was performed retrospectively, using data abstracted from clinical records of subjects seen in 1995-1996. Children were mainly from low and middle economic strata and aged between 6 to 12 years. The following data were collected: age, gender, diagnosis, school grade, food intake, maternal complications during pregnancy, perinatal and postnatal neurological risk factors, and neurological signs and handedness. Results Subjects with RD had a mean age of 102.9 months, were predominantly male (male female ratio, 2:1). Among the study group, $49.1 \%$ of the children were diagno sed with $\mathrm{RD}$ of a visuo-sensory-motor type, and $75.1 \%$ were from early school years ( $1^{\text {st }}$ to $3^{\text {rd }}$ grades); $27.6 \%$ showed evidence of malnutrition.A previous history of language disorders $(49.2 \%)$, and a high frequency of perinatal risk factors and neurological soft signs were also fo und. Conclusions. This study shows that variables such as gender, food intake, and genetic and neurological risk factors, were associated with reading disabilities in school children.The English version of this paper is available too at: http://www.insp.mx/salud/ index.html
\end{abstract}

Key words: reading disability; language disorders; Mexico

\author{
Poblano A, Borja S, ElíasY, \\ García-Pedroza F,Arias ML. \\ Características de la discapacidad específica de lectura \\ en niños de una clínica neuropsicológica \\ en la Ciudad de México. \\ Salud Publica Mex 2002;44:323-327. \\ El texto completo en inglés de este artículo también \\ está disponible en: http://www.insp.mx/salud/index.html
}

\section{Resumen}

Objetivo. D escribir las características clínicas asociadas con los problemas específicos de la lectura en un grupo de 778 escolares estudiados en una Clínica de N europsicología Infantil de la Ciudad de México. Material y métodos. El estudio fue realizado retrospectivamente en los años de 1995 a 1996, con los expedientes clínicos de pacientes de estratos socioeconómicos medio y bajo, valorando las siguientes variables: edad, sexo, diagnostico, grado escolar, alimentación, complicaciones maternas durante el embarazo, factores de riesgo pre-peri y posnatales para daño neurológico, enfermedades neurológicas y lateralidad manual de los pacientes. Resultados Los pacientes con problemas de la lectura tuvieron un promedio de edad de 102.9 meses, fueron predominantemente del sexo masculino (2:1), $49.1 \%$ fueron de tipo visuo-senso-motor, las tres cuartas partes (75.1\%) cursaba los primeros grados de escolaridad, $27.6 \%$ con datos de una ingesta calórico-proteica inadecuada, la mitad con historia de problemas del lenguaje, una alta proporción de factores de riesgo para daño neurológico, así como signos neurológicos blandos. Conclusiones Este estudio sugiere que varias condiciones como sexo, nutrición, factores genéticos y diversos factores de riesgo para daño neurológico están asociados con la presentación de problemas específicos del aprendizaje de la lectura. El texto completo en inglés de este artículo también está disponible en: http://www.insp.mx/salud/index.html

Palabras clave: problemas específicos de la lectura; problemas del lenguaje; México

(1) Instituto de la Comunicación Humana, Centro N acional de Rehabilitación. México, D.F., México.

Received on: N ovember 30,2000 • Accepted on: A pril 3, 2002

Address reprint requests to:Adrián Poblano. Laboratorio de N eurofisiología Cognoscitiva. Instituto de la Comunicación Humana. Centro N acional de Rehabilitación. Calzada México-X ochimilco 289, Colonia A renal Guadalupe, Delegación Tlalpan, 14889. México, D.F., México e-mail:drdyslexia@starmedia.com 
C hildhood Reading Disability (RD) is a generic term that refers to an abnormal difficulty in learning to read and write, presumably as a result of neuropsychological abnormalities in otherwise healthy children. Some authors consider that reading and writing have not exerted evolutionary pressure on humans and therefore no brain specific biological adaptations have occurred for these skills. ${ }^{1}$ Effective treatment depends on early recognition of the underlying disease. ${ }^{2,3}$ Population-based studies suggest that clinical characteristics of RD in children include: a preponderance of males (male: female ratio of 3.5:1), substandard performance in spelling, a frequent history of delayed language milestones, and common familial occurrence. ${ }^{2}$ These features suggest a biological substrate that some authors speculate might be related to cerebral lateralization. In developing countries like Mexico, the clinical characteristics of learning disability (LD) in children may be influenced by malnutrition and socio-cultural disadvantages, as has been suggested by Cravioto et al. ${ }^{4,5}$ The DSM-III and the DSM-IV definitions require that children with LD must have normal intelligence and show evident failure in reading and writing abilities. ${ }^{6,7}$

The epidemiology of RD in underdeveloped countries presents a challenge to the health system, due to the lack of specialists and clinics for treatment of children with RD. In Mexico, only a small proportion of school children have the opportunity to receive care at the few neuropsychological clinics in place. Despite their small numbers, these clinics provide excellent -although not population-based-information on learning disabilities. On the other hand, it is important to remind the health authorities of the need for systematic treatment and clinical care of children with developmental disorders.

The RD literature includes many proposals for classification and subtyping of this clinical entity. However, none of these proposals has gained general acceptance among researchers. Azcoaga et al. ${ }^{8}$ have proposed subtyping focused on developmental neuropsychological performance, such as language-based (expression and comprehensive delay) and non-language-based RD (underperformance in visuo-sensorymotor abilities). The first subtype is probably linguistic and the second one corresponds to the perceptual subtype described by Bakker. ${ }^{9}$ No previous studies have been performed in Mexico to identify the prevalence of both subtypes and additional clinical characteristics of RD children.

The goal of this paper is to describe the main clinical characteristics of school age children with RD, eva- luated by the Children's Neuropsychology Clinic at the Institute for Communication Disorders in Mexico City.

\section{Material and Methods}

The clinical records of 778 patients were reviewed; these subjects had been evaluated and diagnosed with specific reading disability during 1995-1996 at the Children's Neuropsychology Clinic of the Institute for Communication Disorders in Mexico City. Patients were referred mainly by their school teachers or school administrators from neighborhoods surrounding the Institute, which is located in one of the most populated areas of Mexico City. The patients were residents of Mexico City aged between 6 and 12 years, from lower and middle-economic strata $(86.2 \%$ and $13.7 \%$, respectively, according to socioeconomic evaluation by social workers). A diagnosis of reading disability was based on reading age within two or more standard deviations below the mean for children of similar age and intelligence, ${ }^{7,10}$ as established with appropriate testing 8,11 and a battery to assess writing and reading ability in Spanish. ${ }^{12}$ Diagnoses were made according to Azcoaga's classification, with subtyping according to differential deficits. Three main groups were identified: expression delay, comprehensive delay, and underperformance in visuo-sensory-motor abilities. ${ }^{8}$ These tests have been administered for more than ten years in Mexico and are well-established at the Institute, which has now accumulated a vast experience in applying and interpreting them $\mathrm{RD}$ diagnosis.

Clinical histories were performed by three specialist in child communication disorders with a percent of concordance of $99 \%$ in neuropsychological diagnoses. Neuropsychologic and neurophysiologic tests were also performed on each patient but results from those tests are not included in the present report. Data from clinic records included: (a) age; (b) gender; (c) clinical diagnosis; (d) school grade level; (e) food intake noted in the clinic history using a questionnaire, ${ }^{13}(\mathrm{f})$ perinatal and postnatal neurological risk factors and maternal complications during pregnancy; $(\mathrm{g})$ neurological examination, ${ }^{14}$ and (h) handedness. ${ }^{15}$ Descriptive data of the sample are presented as percentages and cumulative frequencies of the whole study population.

\section{Results}

A total of 778 subjects aged 6-12 years (average 102.9 months or 8.6 years)were included in the study. The male/female ratio was 2:1. Three hundred and eighty 
two patients (49.1\%) were diagnosed with a visuo-sensory-motor type of $\mathrm{RD}$, three hundred and forty four $(44.2 \%)$ showed a language plus non-verbal deficit alteration type, and fifty two $(6.6 \%)$ were in the expression delay group.

Of the 778 children studied, $75.1 \%$ were in the first school grades $(1,2,3)$ and the remainder $(24.8 \%)$ in the higher grades of elementary school (Table I). Food intake was clinically qualified as a lower caloric/protein intake in $27.6 \%$ of the group (215 patients).

One or more maternal complications during pregnancy were noted in $21.4 \%$ of subjects. The main complications were: transvaginal bleeding $(n=113,67.7 \%)$, preclampsia $(\mathrm{n}=21,12.6 \%)$, pregnancy after 35 years $(n=21,12.6 \%)$, and hypertension $(n=12,7.2 \%)$. The main perinatal risk factors found were: hyperbilirubinemia ( $n=121,15.5 \%$, including 3 patients who required transfusions, and 47 who received phototherapy), asphyxia $(\mathrm{n}=88,11.3 \%)$, and preterm birth $(\mathrm{n}=55$ cases, $7 \%)$.

Motor development was delayed in 60 patients $(7.7 \%)$, and language development delay was detected in 383 patients (49.2\%) prior to the diagnosis of RD. A postnatal neurological history disclosed mild head traumatism without loss of consciousness in 162 patients $(20.8 \%)$, spells of apnea in 110 patients (14.1\%), attention deficit-hyperactivity disorder in 35 patients $(4.5 \%)$, and febrile seizures in 30 patients $(3.8 \%)$.

The more common soft neurological signs were dysgraphystesias in 185 patients $(23.7 \%)$, dysterognosias in 54 patients $(6.9 \%)$, hand dyspraxias in 43 patients $(5.5 \%)$, dysdiadochokinesia in 40 patients $(5.1 \%)$, and dysmetry in 39 patients. The investigation of handedness showed that $98.4 \%$ (766 patients) were right-handed and only $1.5 \%$ (12 patients) were lefthanded.

\section{Table I \\ Distribution OF CHILDREN BY SCHOOL GRADE. Mexico City, 1995-1996}

\begin{tabular}{lccc} 
Grade & $n$ & $\%$ & af \\
$1^{0}$ & 145 & 18.6 & 18.6 \\
\hline $2^{0}$ & 260 & 33.4 & 52.0 \\
\hline $3^{0}$ & 180 & 23.1 & 75.1 \\
\hline $4^{0}$ & 112 & 14.4 & 89.5 \\
\hline $5^{0}$ & 61 & 7.8 & 97.3 \\
\hline $6^{0}$ & 20 & 2.6 & 99.9 \\
$\%=$ percent & & \\
af = cumulative frequency & & \\
\hline
\end{tabular}

\section{Discussion}

The present work included only children treated in the neuropsychological clinic, and not the general elementary school population. Our results are thus limited only to the urban population with access to specialized health care services. Despite these methodological limitations, to our knowledge no previous studies have been performed in Mexico to describe the main clinical characteristics of RD children. No association between RD children and risk factors were explored and no statistical analyses were conducted to measure correlations between variables, thus in the discussion we only comment on possible relationships among variables that cannot be considered as strong conclusions.

It is now recognized that children with RD may present some neuropsychological alterations. Our sample shows that diagnosis were performed mainly from the first to the third grade of elementary school ( $75.1 \%$, see Table I), which indicates the interest of parents and teachers of children with these conditions. Delayed diagnosis may result in mild disabilities. However, the average age in our study population (8.6 years) shows a delayed diagnosis, which may be due to the lack of information of school teachers leading to delayed identification and referral of RD children to the neuropsychological services.

Characteristics of RD in children from other studies include a higher prevalence in males, consistent with the male/female 2:1 ratio, similar to that found in a study conducted in the Isle of Wight. ${ }^{16}$ However, methodological and population differences between studies suggest caution in making comparisons. In underdeveloped countries such as Mexico, the parents have the idea that males will be the economic support of the family, and thus the female difficulties at school do not receive the same attention. Recently, some investigators have shown that this bias is important and suggest that boys and girls present similar frequency of $\mathrm{RD} .{ }^{17}$ In the future this hypothesis deserves more attention.

The frequency of RD alterations in underdeveloped countries is unknown. ${ }^{8}$ In our study visuo-sensory-motor disabilities (49.1\%) and mixed group $(44.2 \%)$ were the most frequent types of alterations. Pure expressive language deficit were the less frequent $(6.6 \%)$.

Some researchers believe that learning disabilities occur at higher rates in families with low nutrition levels, which may occur with greater frequency in underdeveloped countries. A relationship between poverty, malnutrition and academic failure is well established. ${ }^{18}$ 
In our study we found that almost one third of the patients may have suffered some degree of malnutrition. Some of the main alterations in mental development on school performance correlated with infant malnutrition were: Delayed vocabulary and learning achievement, impaired visual perception and impaired visual-kinesthetic and auditory-visual intersensory integration. ${ }^{4,5}$ These conditions may help to explain poor school performance.

Our study results also seem to suggest a possible role of obstetric and perinatal events in the development of RD. Studies about risk factors for neurodevelopment disabilities can prove this observation. ${ }^{19}$ The relationships between obstetric and neurological conditions of the infant were not clear in our sample. For example, transvaginal bleeding is a possibly damaging obstetrical risk factor that may increase neurological damage and secondarily RD, but its influence could not be ascertained; the only significant relationships found in the literature refer to asphyxia and $\mathrm{RD} .{ }^{20} \mathrm{At}$ present, the relationship between perinatal risk factors and learning disabilities is still under study. The majority of prospective studies deals with low-birth weight infants and indicates an increased frequency for learning disabilities, ${ }^{21,22}$ but the literature on this issue topic is not conclusive. In our study, the most common perinatal events and maternal complications were neonatal jaundice, asphyxia, and transvaginal bleeding.

Some investigators suggest that RD is related to language disorders. ${ }^{3,23}$ In our study we found that almost half our patients (49.2\%) showed delayed language milestones. On the other hand, the parents of children diagnosed with specific language impairments showed a higher frequency of learning problems. ${ }^{24}$ Many studies suggest that there exists a familial factor that may reflect a genetic component. ${ }^{25,26}$ The Mendelian mode of transmission remains unclear, but recent works suggested that specific learning disabilities are associated with chromosomes 15 and 6.27,28 Future studies of risk factors must be undertaken to investigate the genetic basis of learning disabilities.

Head trauma and apnea spells ${ }^{29,30}$ were frequently observed by parents of RD children in this study, but these factors may be over-estimated due to parental anxiety and unfamiliarity with the etiology of RD. On the other hand, not enough research has been undertaken to identify a relationship between mild head trauma and apnea spells with RD. The majority of head trauma reported by the parents in our group did not result in loss of consciousness or brain injury. For this reason it is hard to relate these reports to the learning disability.
We found many soft neurological signs that were suggestive of central nervous system pathology, which frequently had a transient quality. An increased frequency of subtle neurological abnormalities has been observed in children with RD in other studies. ${ }^{31}$ The soft neurological signs more frequently found are those involving fine movements, asymmetries, dyskinesia, visual-motor coordination, sensory integration, laterality, right-left discrimination, and clumsiness. In our study dysgraphystesia was the most common sign.

An association between learning disabilities and left-handedness and immune diseases has been proposed previously, ${ }^{32}$ but it was not clearly observed in our study. Despite a direct search for immune disorders in the hospital records of our patients, only a few cases with auto-immune alterations were detected and thus are not shown in the tables. No surveys of learning disabilities in left-handed children in the general school population support this hypothesis, however some studies show that poor readers tend to have weak left hand skills. ${ }^{33}$ Our work was not designed to research this issue.

In conclusion, our data suggest that in a specialized Neuropsychological Clinic from Mexico City, reading disabilities may be associated to many variables such as: gender, language development, food intake, frequency of perinatal risk factors, and neurological soft signs. On the other hand, probabilistic population studies and school screenings must be undertaken in the future, to assess the true risk factors of reading disability behavior in Mexico.

\section{Acknowledgments}

We are grateful to Patricia Muñiz, MD for her collaboration, and to Robert Burns, $\mathrm{PhD}$, for his help in correcting the manuscript. Thanks to the anonymous reviewer for recommending on-line information on Learning Disabilities in the website www.ldonline.org.

\section{References}

1. Dalby JT. An ultimate view of reading ability. Inter J N eurosci 1986;30: 227-230.

2. D uane DD. N eurobiological correlates of learning disorders. J Am A cad Child Adolesc Psychiatr 1989;28:314-318.

3. Shawitz SE. Dyslexia. N Engl J Med 1998;338:307-312.

4. Cravioto J, Cravioto P. Some long-term psychobiologic consequences of malnutrition. Ann N estle 1990;48:93-102.

5. Cravioto J,Arrieta R. N utrición, desarrollo mental, conducta y aprendizaje. México, D.F.: Instituto N acional de Ciencia y Tecnología-D IF, 1985.

6. Asociación Psiquiátrica Americana. DSM-III. Manual Diagnóstico y Estadístico de los Trastornos Mentales. Barcelona: Masson, 1987. 
7. Asociación Psiquiátrica Americana. DSM-IV. Breviario. Criterios Diagnósticos. Barcelona: Masson, 1995.

8. Azcoaga J, Derman B, Iglesias PA. Alteraciones del aprendizaje escolar. Diagnóstico, fisiopatología y tratamiento. Barcelona: Paidós, 1985.

9. Bakker DJ. N europsychological classification and treatment of dyslexia. J Learn D is 1992;25:102-109.

10. Gersons-W olfensberger DCM, Ruijssenaars W AJJM. D efinition and treatment of dyslexia: A report by the Committee on Dyslexia of the Health Council of the N etherlands. J Learn D is 1997;30:209-213.

11. N ieto M. El niño disléxico. México, D.F.: La Prensa Médica Mexicana, 1980.

12. Ezcurra M. Identificación de los patrones de distorsión en la lectoortografía en la lengua española como elemento diagnóstico de dislexia de evolución. Adaptación transcultural de la investigación de la doctora Elena Boder. Memorias del II Congreso Hispano-Americano de Dificultades en el A prendizaje de la Lectura y Escritura. México, D.F.:Secretaría de Educación Pública, 1974:760-795.

13. Hernández-Avila M, Romieu I, Parra S, Hernández-Avila J, Madrigal H, $W$ illet W.Validity and reproducibility of a food frequency questionnaire to assess dietary intake of women living in Mexico City. Salud Publica Mex 1998:40:133-140

14. Touween BL. Examen del niño con disfunción encefálica mínima. Buenos Aires: Panamericana, 1986.

15. O ldfield RC. The assessment and analysis of handedness: The Edinburgh Inventory. N europsychology 1971;9:97-113.

16. Rutter M, Yule W, Graham P,W hitemore K. Research report: Isle of W igth Studies 1964-1974. Psychol Med 1976;6:313-332.

17. Shaywitz SE, Shaywitz BA, Fletcher JM, Escobar MD.Prevalence of reading disability in boys and girls. Results of the Connecticut Longitudinal Study. JAMA 1990;264:998-1002.

18. Campbell FA, Ramey CT. Effects of early intervention on intellectual and academic achievement: A follow-up study of children from low-income families. Child Dev 1994;65:684-698.

19. Kenworthy OT, Bess FH, Stahlman MT, Lindstrom D P. Hearing, speech, and language outcome in infants with extreme immaturity. Am J 0 tol 1987;8:419-425

20. Robertson CMT, Finer N N , Grace MGA. School performance of survivors of neonatal encephalopathy associated with birth asphyxia at term.J Pediatr 1989;114:753-760.
21.Vohr BR, García-C oll CT.N eurodevelopmental and school performance of very low-birth-weight infants: A seven-year longitudinal study. Pediatrics 1985;76:345-350.

22. Hack M, Breslau N, W eissman B,Aram D, Klein N, Borawsky E. Effect of very low birth weight and subnormal head size on cognitive abilities at school age. N Engl J Med 1991;325:231-237.

23. Poblano A,Valadez-Tepec T, Arias ML, García-Pedroza F. Phonological and visuo-spatial working memory alterations in dyslexic children. Arch Med Res 2000;31:493-496.

24. Tomblin JB, Smith E, Zhang X. Epidemiology of specific language impairments: Prenatal and perinatal risk factors. J Commun Disord 1997; 30:325-344.

25. Gillis-Light J, DeFries JC. C omorbidity of reading and mathematics disabilities: Genetic and environmental etiologies. J Learn D is 1995;28: 96-106.

26. DeFries JC, Fulkner DW, LaBuda MC. Evidence for a genetic aetiology in reading disability of twins. $N$ ature 1987;329:537-539.

27. Cardon LR, Smith SD, Fulkner DW, Kimberling W J, Pennington BF, de Fries JC. Q uantitative trait locus for reading disability of twins. $N$ ature 1987;329:537-539.

28. Smith SD, Pennington BF, KimberlingW J, Lubs HA.A genetic analysis of specific reading disability. En:Smith SD, ed. G enetic aspects of speech and language disorders. N ueva York: A cademic Press, 1983:169-178.

29. Ruff RM, Young D, G autille T, Marshall LF, Barth J, Jane JA et al. Verbal learning deficits following severe head injury: Heterogeneity in recovery over 1 year. J N eurosurg 1991;75:S50-S58.

30. Hannon DW. Breath-holding spells:W aiting to inhale, waiting for systole, or waiting for iron therapy.J Pediatr 1997;130:510-512.

31.ArdilaA.C orrelation between scholastic performance and soft neurological signs in children. Int Pediatr 1996;11:284-287.

32. Geschwind N , Behan P. Left-handedness:Association with immune disease, migraine, and developmental learning disorder. Proc $\mathrm{N}$ atl Acad Sci 1982;79:5097-5100.

33. Annet M, Manning M. Reading and a balanced polymorphism for laterality and ability. J Child Psychol Psychiatr 1990;31:511-529. 